\title{
BLOOD SERUM FLUORIDE LEVELS WITH METHOXYFLURANE ANAESTHESIA
}

\author{
Allen B. Dobkin, M.D. ANd Ashley A. Levy, PH.D. *
}

Ever SINCE Pringle and Thompson, ${ }^{1-2}$ in 1905, reported that diethyl ether and chloroform anaesthesia respectively reduced urine output, and Smith, Rovenstine and associates, ${ }^{3}$ in 1939 , reported in a similar effect with spinal anaesthesia, close attention has been paid to the effect of all anaesthetics, surgical trauma, and analgesics on the function of the kidney. ${ }^{4-5}$

Until approximately 10 years ago, inhalational and parenteral anaesthetics administered judiciously and even in moderate overdose had not been found to cause a direct adverse effect on the renal parenchyma in animals or man unless they accompanied or followed severe surgical trauma and multiple blood transfusions. Nevertheless, urine output is almost invariably reduced during surgical anaesthesia, with reductions in renal blood flow, glomerular filtration rate and osmolar clearance. These effects usually respond to forced diuresis with intravenous fluids (dextrose, saline or balanced salt solutions in water). In our practice, an osmotic diuretic such as mannitol is also given, usually when the urine output falls below $40 \mathrm{ml} / \mathrm{hr}$. These manoeuvres usually increase urine output promptly. ${ }^{6}$ The oliguria which occurs during anaesthesia is followed frequently by a moderate postanaesthetic compensatory polyuria, as glomerular filtration rate and renal blood flow are restored, or the liberation of antidiuretic hormone ceases. These effects may be contingent upon many other factors such as the amount of analgesics administered postoperatively, the presence of preexisting renal or cardiopulmonary disease under drug therapy, and the use of antibiotics or other therapeutic agents that may be nephrotoxic. ${ }^{5,7}$

Following the clinical introduction of methoxyflurane in 1960, the question of a toxic effect on the kidney arose again, especially in centers where operations were often prolonged. ${ }^{8,9,10}$ Methoxyflurane anaesthesia produces a similar renal response to that described above. The reduction of glomerular filtration rate with this anaesthetic may result as a consequence of a fall in renal perfusion pressure or of constriction of the afferent renal arterioles, all of which cause retention of salt and water. ${ }^{4}$ After extensive animal and clinical evaluations, our recommendation was that 1.5 per cent methoxyflurane should never be exceeded and this agent should only be used with nitrous oxide for maintenance of anaesthesia for major or prolonged operations, after induction of anaesthesia with a rapid-acting anaesthetic. ${ }^{11,12}$

Clear-cut evidence of nephrotoxicity of methoxyflurane vapour itself had still

"From the Department of Anesthesiology, State University Hospital, State University of New York, Upstate Medical Center, Syracuse, New York, 13210, U.S.A.

Presented at the Annual Meeting of the Canadian Anaesthetists' Society at Halifax, Nova Scotia, Canada, June 22, 1972. 
not appeared. In 1966, scattered reports of such a connection began to be published. Subsequently, a postoperative syndrome was identified, specifically related to the administration of this agent. Some of the reports implicated the anaesthetic alone as the culprit and others surmised an interaction or association with other drugs known to be nephrotoxic. ${ }^{13-18}$ The main features of the syndrome, occurring after at least two hours of methoxyflurane anaesthesia, consisted of the development of marked polyuria with urine of low specific gravity within 24 hours after surgery, negative fluid balance and weight loss (when fluid losses were not replaced!), elevated serum sodium and chloride and increased serum osmolality, and elevated blood uric acid and urea nitrogen. The urine osmolality did not respond to fluid deprivation, rapid fluid infusion or pitressin. In most cases, the concurrent replacement of fluid losses was successful in alleviating this pathological condition. ${ }^{13}$ In the few patients who died and who had a postmortem examination, no typical or consistent lesions were found in the kidney, although tubular disruption was cited. Lesions described were similar to those found in patients who never had received any anaesthesia (e.g., oxalate crystals, tubular necrosis).

During the past few years, sophisticated methods have been developed which facilitate the identification even in minute amounts of metabolic breakdown products from inhalational anaesthetics. ${ }^{19}$ Until recently, it was believed that all inhalational anaesthetics except trichlorethylene were eliminated entirely unchanged through the lungs. It appears now that up to 35 per cent of the inhaled anaesthetic vapours may be biodegraded and, in the case of methoxyflurane, toxic products may accumulate in sufficient quantity to injure vital organs - particularly the kidney. ${ }^{20}$ There is now good evidence that methoxyflurane is metabolized by two routes, releasing mainly inorganic fluoride and chloride ion and several acids, including dichloracetic, methoxydifluoroacetic and oxalic acid. ${ }^{21}$ Both the fluoride ion and oxalic acid may cause toxic effects. Whether butylated hydroxytoluene .01 per cent, the anti-oxidant in methoxyflurane, contributes to toxicity is not known, but it is unlikely.

The ingestion of fluoride ion in minute quantities by man, be it inadvertently from the room air or aerosols, or purposely in toothpaste or in drinking water containing one part per million (i.e., 52 micromoles per litre) - is beneficial to the teeth and moderate excess is usually stored in the bones and does no harm; indeed it has even been suggested for treatment of bone discase. ${ }^{22,23}$ If excess ingestion occurs chronically, the bones become very hard and brittle, the teeth become mottled, and the subject suffers from nausea, epigastric distress and diarrhoea. ${ }^{24}$ Acutely, if the blood level exceeds approximately $75 \mu \mathrm{M} / \mathrm{L}$, marked polyuria and salt retention are likely to occur..$^{20}$ Renal parenchymal damage was demonstrated in man as early as 1931 by Goldemberg, when blood levels in the $200 \mu \mathrm{M} / \mathrm{L}$ range occurred after feeding sodium fluoride for an extended period to patients with goitre. ${ }^{25}$ Recently, Cousins, Mazze and their colleagues were able to produce similar effects in man by administering methoxyflurane in high inhaled concentrations for a prolonged period. They subsequently confirmed that the effect only occurred when methoxyflurane was given in excess, and renal symptoms were due to the accumulation of inorganic fluoride ion. ${ }^{21,26}$

The following study was carried out to determine whether methoxyflurane given 
by the anaesthetic technique employed in our institution for the past 12 years causes a marked accumulation of fluoride ion.

\section{Materials and Methods}

Each of the patients in this investigation had been scheduled for an elective major abdominal operation. Blood serum assays for inorganic fluoride ion were done with a specific Orion electrode by the method described by Fry and Taves. ${ }^{27}$

The agents studied included a balanced anaesthesia technique using nitrous oxide-oxygen with diazepam (Valium ${ }^{\circledR}$ ) and morphine. This technique was used as our non-fluorinated control system. The remainder of the cases were done with halothane (Fluothane $\left.{ }^{\circledR}\right)$, methoxyflurane (Penthrane ${ }^{\circledR}$ ), enflurane (Ethrane)* and isoflurane (Forane) ${ }^{*}$. The effect of the latter two agents will be reported separately.

For each patient, light premedication was used, consisting of atropine or scopolamine ( 0.3 to $0.4 \mathrm{mg}$ ), usually with one of diazepam ( 5 to $10 \mathrm{mg}$ ), meperidine ( 25 to $50 \mathrm{mg}$ ) or Innovar ${ }^{\circledR}$ ( 1 to $2 \mathrm{ml}$ ), one hour prior to induction of anaesthesia.

In the patients who were managed with the "balanced" technique, induction was usually carried out with nitrous oxide-oxygen by mask plus diazepam intravenously until unconsciousness was evident, or with a sleep dose of thiopentone; then 60 to $100 \mathrm{mg}$ of succinylcholine was given intravenously, followed by manually controlled hyperventilation of the lungs for approximately one minute, then endotracheal intubation. Maintenance of anaesthesia was carried out with nitrous oxide and oxygen (3:2) with a 7.5 to 10 litre gas flow, a non-deplorarizing muscle relaxant (usually d'tubocurarine), and then small doses of morphine or fentanyl (Sublimaze $\left.{ }^{(}\right)$as needed. At the end of the operation, reversal of muscle relaxants and narcotics were used only if spontaneous pulmonary ventilation was inadequate or return of consciousness was slow ( $>30$ minutes). This seldom occurred.

Anaesthesia in all other patients was induced with a weight-related dose of a non-depolarizing muscle relaxant followed immediately by a sleep dose of thiopentone ( 200 to $500 \mathrm{mg}$ ), manual hyperventilation of the lungs with 100 per cent oxygen for three minutes, oral endotracheal intubation and, after checking airentry in the lungs, connection to a mechanical respirator set to produce a slight hyperventilation by establishing the rate at 12 to 16 per minute and the tidal volume at 7 to $10 \mathrm{ml} / \mathrm{kg}$. Maintenance of anaesthesia was carried out with nitrous oxideoxygen (3:2) and the inhalation agent being tested, which was delivered from a calibrated Cyprane ${ }^{\circledR}$ vapourizer calibrated for the particular agent. Initially, the vapour concentration of halothane was set at 1.0 to 2.0 per cent, then was gradually reduced to 0.5 to 1.0 per cent. Additional non-depolarizing muscle relaxant was given in small doses, as necessary. With methoxyflurane, the inhaled concentration was set at 1 per cent initially and, after start of the operation, was reduced to between 0.2 per cent and 0.5 per cent, thus ensuring that the inhaled concentration was sufficient to maintain operating conditions satisfactory to the surgeon. Additional doses of muscle relaxant were seldom required in this group. During surgical

'Generic and trade names respectively of Ohio Medical Products, Division of Air Reduction Company, Inc. 
closure, the methoxyflurane was gradually turned to "off" in the cases which exceeded four hours. During skin closure, the nitrous oxide was also turned off and the oxygen flow was increased. ${ }^{11,12,28}$

A "control" blood sample for fluoride ion assay was drawn when the intravenous infusion needle or plastic catheter was inserted before induction of anaesthesia. A second sample was drawn after one hour of anaesthesia had elapsed, and a third sample was drawn approximately 10 minutes after the patient was settled in the recovery room.

Infusion fluids during anaesthesia included lactated Ringer's, 0.9 per cent saline, and 5 per cent dextrose in water. Whole blood, packed cells or blood fractions were given as required. None of these patients received an ethanol infusion.

All patients were monitored in routine fashion: blood pressure by sphygmomanometer or by an intra-arterial needle - strain gauge - oscilloscope arrangement, electrocardiograph-oscilloscope, arterial blood gases on Instrumentation Laboratory instruments - if considered necessary, rectal or oesophageal temperature and urine output (catheter drainage into a calibrated trap). As noted above, pulmonary ventilation was controlled in all study cases, employing a mechanical respirator. Disposable (unused) or aerated gas-sterilized corrugated delivery hoses were attached to the gas-machine prior to each study case. Different vapourizers specifically reserved for the particular liquid inhalation anaesthetics were always used and placed outside the circle system. Not more than one vapourizer was in a circuit at one time during these tests in order to avoid vapour contamination.

\section{Results AND Discussion}

The results of this investigation consist of a report of our fluoride data on 91 patients who received balanced anaesthesia (control system), 101 patients who received halothane, and 105 patients who received methoxyflurane. These data are summarized on Tables $I$ and II and Figures 1, 2 and 3. As can be seen in Table I, the groups are comparable in number as to age and sex. The mean anaesthesia time is longer in the balanced group due to at least 4 cases that were unusually prolonged ( 6 to 8 hours). Each patient was closely followed for several days postoperatively. None developed anaesthesia-related toxic symptoms.

It was expected that at the beginning of the study all patients would have about the same blood serum concentration of inorganic fluoride ion. This indeed was the case, and the value was approximately $1.7 \mu \mathrm{M} / \mathrm{L}$. Drinking water in the Syracuse, New York area is fluorinated and the value noted above is probably typical for all inhabitants of this area who drink public water. This serum inorganic fluoride level corresponds to one-thirtieth part per million ( see Table II).

As anaesthesia progressed, there was a slight rise in the serum inorganic fluoride level in the patients who received balanced anaesthesia or halothane. Following thorough testing of the intravenous infusion fluids, blood for transfusions and blood bags, we came to the conclusion that the negligible amounts contained therein could not account for the observed change. We decided that the rise was probably due to mobilization of fluoride already in the body plus trace amounts that may be picked up from aerosols in the room-air and fluoride contained in 
TABLE I

Some Vital Data on Patients in this Study

\begin{tabular}{|c|c|c|c|}
\hline & Balanced & Halothane & Methoxyflurane \\
\hline Number of patients & 91 & 101 & 105 \\
\hline $\begin{array}{l}\text { males } \\
\text { females }\end{array}$ & $\begin{array}{l}33 \\
58\end{array}$ & $\begin{array}{l}40 \\
61\end{array}$ & $\begin{array}{l}36 \\
69\end{array}$ \\
\hline $\begin{array}{l}\text { Mean age } \pm \text { S.E.M. } \\
\text { Age spread }\end{array}$ & $50.7 \pm 1.8$ & $48.0 \pm 1.7$ & $\begin{array}{l}46.2 \pm 1.6 \\
19 \text { to } 87\end{array}$ \\
\hline \multirow{2}{*}{$\begin{array}{l}\text { Duration of anaesthesia } \\
\text { (mean in minutes) }\end{array}$} & & & \\
\hline & 210 & 161 & 166 \\
\hline
\end{tabular}

TABLE II

Comparison of Mean Serum Inorganic Fluoride Levels MICROMOLES PER LITER I STANDARD ERRORS OF MEAN

\begin{tabular}{lccc}
\hline \multicolumn{1}{c}{ Primary anesthetic } & Balanced & Halothane & Methoxyflurane \\
\hline Number of patients & 91 & 101 & 105 \\
F $^{-}$before anaesthesia* & $1.74 \pm .09$ & $1.60 \pm .08$ & $1.80 \pm .11$ \\
F- $^{-}$mo min. anaesthesia & $2.27 \pm .22$ & $2.18 \pm .17$ & $15.35 \pm .59$ \\
F $^{-}$after anaesthesia & $2.46 \pm .24$ & $2.40 \pm .17$ & $19.91 \pm .79$ \\
\hline
\end{tabular}

*Serum inorganic fluoride.

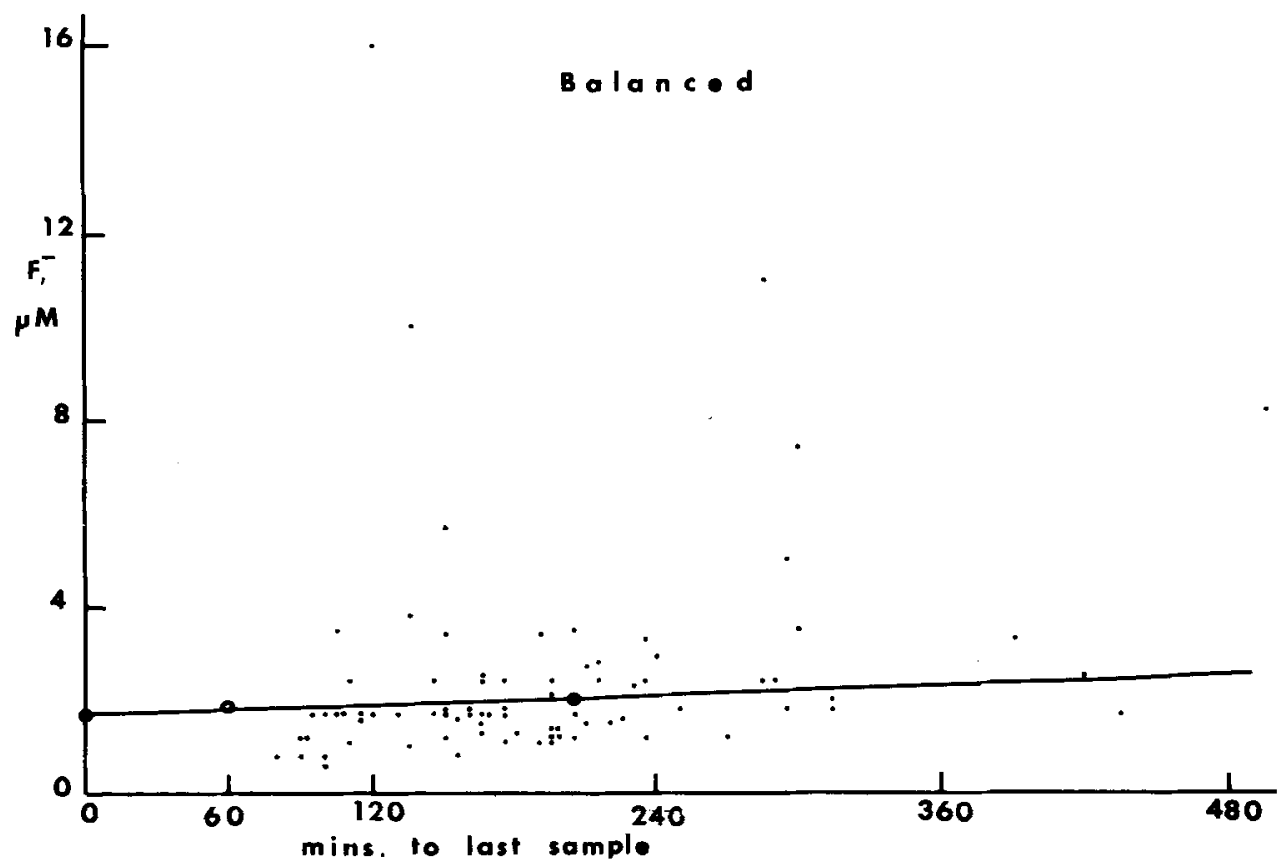

Figure 1. Serum fluoride at end of balanced anaesthesia ( 91 patients). Note that mean duration of anaesthesia was 210 minutes and that all but six end serum samples were below $4 \mu \mathrm{M} / \mathrm{litre}$. The maximum ( 1 patient) did not exceed $16 \mu \mathrm{M} /$ litre. 


\section{Halothane}

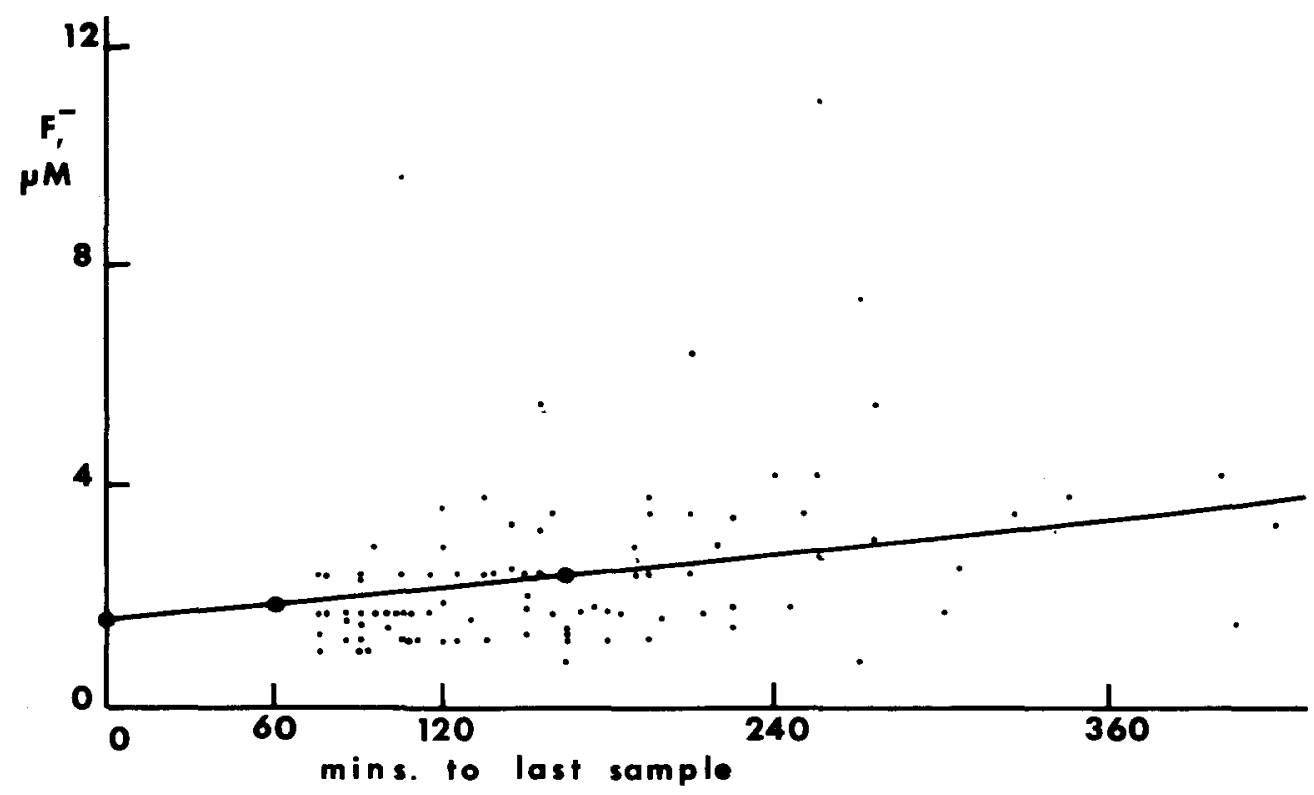

Figure 2. Serum fluoride at end of halothane anaesthesia ( 101 patients). Note that mean duration of anaesthesia was 161 minutes and that all but six end serum samples were below $4 \mu \mathrm{M} /$ litre. The maximum ( 1 patient) did not exceed $12 \mu \mathrm{M} /$ litre.

parts of the anaesthetic machines and respirators that are not easily cleaned or replaced. It was evident from these data that even though halothane is metabolized in the body to an appreciable degree (up to 25 per cent), free inorganic fluoride ion does not accumulate in the blood serum because the trifluoroacetic acid formed is very stable. There was no source of fluoride ion evident during balanced anaesthesia (see Figures 1 and 2).

With methoxyfluorane, the data were quite different. Assay of the control blood serum samples revealed approximately the same amount of inorganic fluoride ion as in the other two groups. At 60 minutes, the assay revealed almost a ten-fold increase over the controls. Evidently the body has a quick process for metabolizing methoxyflurane. Assay data of the samples drawn at the end of anaesthesia were surprising in that the serum inorganic fluoride continued to rise only at a relatively slow rate - that is, about one-tenth the rate of the initial 60 - to 70 -minute rate of rise, and within the same order of magnitude as was seen in the patients who received halothane and balanced anaesthesia. With a mean duration of just over 165 minutes of anaesthesia in the methoxyflurane series (105 patients) in the 90 minutes after the first hour, if the rate of rise had continued as in the first hour, the serum fluoride would have reached about $35 \mu \mathrm{M} / \mathrm{L}$, whereas the mean level found was approximately $20 \mu \mathrm{M} / \mathrm{L}$ (see Figure 3 and Table II). Moreover, the actual highest level observed was just less than $50 \mu \mathrm{M} / \mathrm{L}$ (in 2 cases). All of the remaining maximum levels were below $40 \mu \mathrm{M} / \mathrm{L}$. These included 16 patients who had between four and six hours of anaesthesia. 


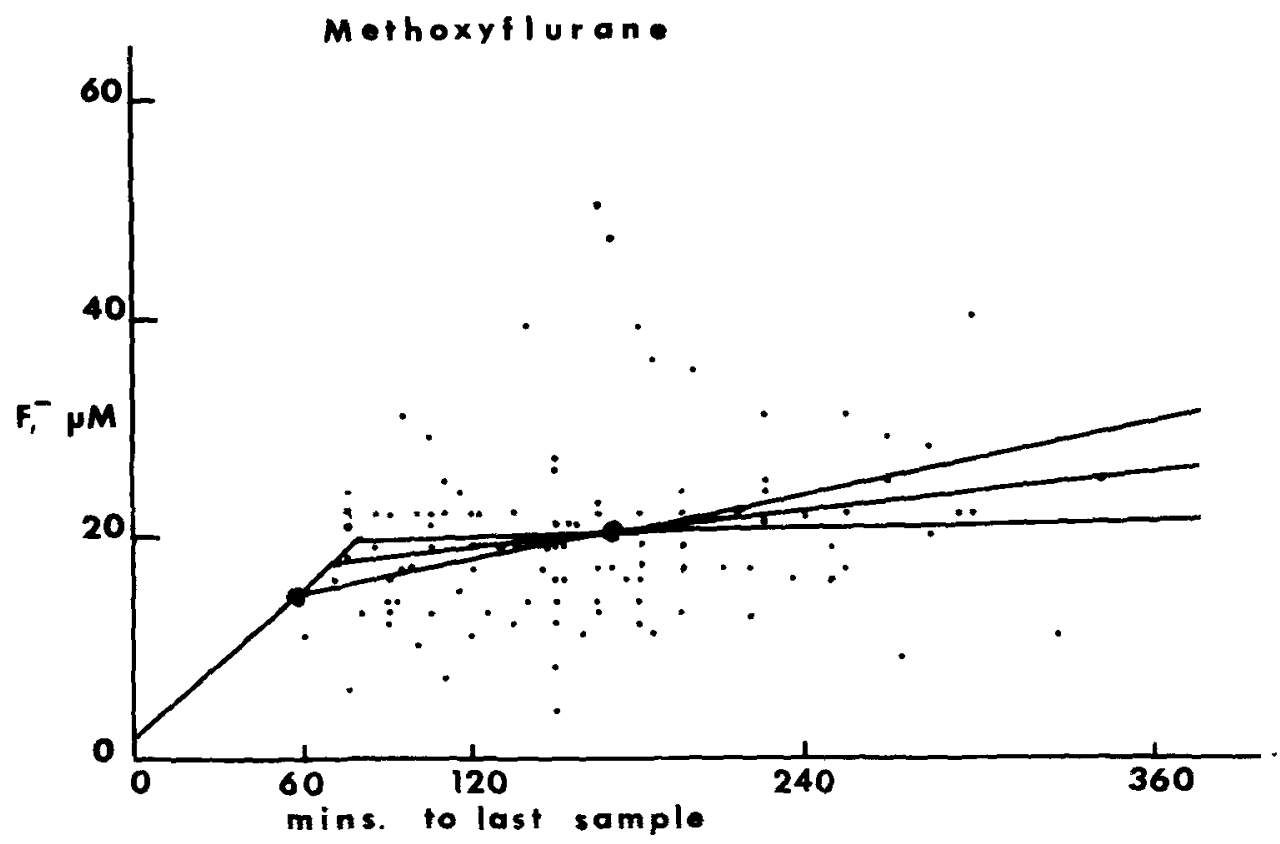

FIgure 3. Serum fluoride at end of methoxyflurane anaesthesia ( 105 patients). Mean duration of anaesthesia was 166 minutes. Note that, statistically, the serum fluoride value peaked in 60 to 70 minutes, at approximately $20 \mu \mathrm{M} /$ litre, then rose gradually thereafter at a very slow rate. The maximum level reached (in 2 patients) was between 40 and $50 \mu \mathrm{M} /$ litre and only seven patients exceeded $30 \mu \mathrm{M} /$ litre. Correlation between duration of anaesthesia and serum fluoride concentration was not significant (center line is mean value and other 2 lines are the 95 per cent confidence limits ).

It appears, therefore, that serum inorganic fluoride levels do not keep rising rapidly with increasing duration of methoxyflurane anaesthesia. A plateau is evidently reached in the rise of serum fluoride after the first hour or so. From these data it appears that when the serum fluoride level reaches between 15 and $30 \mu \mathrm{M} / \mathrm{L}(0.35$ to $0.6 \mathrm{ppm})$, its excretion keeps pace with its generation from metabolism or mobilization when methoxyflurane is administered at a clinically useful concentration for major abdominal operations.

It is interesting to note that Van Dyke has just revealed a similar abservation in his experiments with methoxyflurane in rodents. ${ }^{29}$

\section{Conclusions}

It is estimated that over 20 million anaesthetics have been given with methoxyflurane for major operations. This excludes its widespread use for obstetrical analgesia. It is a useful anaesthetic agent because of its potent analgesic, hynotic and muscle relaxant properties, and for the absence of appreciable cardiovascular depression or cardiac arrhythmias. It is non-explosive, compatible with catecholamines, does not stimulate salivary secretions, and is relatively cheap because of its great potency (especially with respect to analgesia). ${ }^{30-34}$ The toxic effects that 
have been reported are actually rare occurrences and, in most cases, probably represent overdosage.

As with all anaesthetics, a reduction in water and electrolyte excretion via the urine occurs during its administration due to a number of uncertain factors including increased ADH secretion and reduced renal blood flow, followed in a day or more by compensatory polyuria. In well-hydrated subjects with good water diuresis, induction of anaesthesia results in marked reduction in urine volume, in increase in osmolality of the urine, and conversion of a positive free water clearance, i.e., a dilute urine, to a negative free water clearance - which is indicated by a very concentrated urine. Osmolar clearance as well as sodium and potassium excretion are also significantly reduced during general anaesthesia. Aldosterone liberated from the adrenal cortex during anaesthesia may also cause reduced sodium excretion. ${ }^{5}$ Many elderly patients are brought to operation "dried out" by their physicians because of cardiac, pulmonary and vascular disease - presenting a more complicated situation than described above. If fluid losses are not adequately replaced before or during operation, a syndrome develops which is not unlike that seen with the administration of theophylline-containing diuretics, marked by hypotonic diuresis, dehydration, weakness, lassitude and confusion.

After methoxyflurane anaesthesia, some unusual effects have been observed. These are undoubtedly the key to the problem of renal dysfunction that may occur with this agent. Fluoride ion, which has long been known to be toxic to the kidney, is released in the metabolism of this anaesthetic. This study indicates that, if methoxyflurane is given judiciously, a peak concentration of fluoride ion is reached relatively quickly and it can be excreted by the kidney almost as rapidly as it is generated. If excessive methoxyflurane anaesthesia is administered either due to a high administered concentration or because of a prolonged operation, the kidney evidently cannot keep up with the accumulation of the fluoride ion and the concentration in the serum rises to levels which may damage this vital organ. However, to attain a fluoride concentration in the blood that will probably cause renal tubular damage, at least three times the concentration of methoxyflurane needed for surgical anaesthesia must be inhaled for several hours. Whether the preservative in methoxyflurane augments the renal toxicity is not known, but this is unlikely. The renal effect is probably aggravated if fluid replacement does not keep up with blood and electrolyte losses and perhaps the incidence of renal dysfunction can be increased if tetracycline is administered concurrently.

When three times the inhaled concentration required for surgical anaesthesia of any inhalational anaesthetic agent is administered, undesirable effects on vital organs can be expected in at least as high a proportion as has been attributed by some to the effect of methoxyflurane, although other organs or vital signs may be involved. ${ }^{10,21}$

The literature on this entire subject has been extensively reviewed by others. It appears that several of the case reports of nephropathy were undoubtedly due to mis-management, inexperience or concurrent problems, such as preexisting kidney disease, prolonged deep anaesthesia, interaction with nephrotoxic drugs (tetracycline, diuretics, etc.).

Our previous studies confirm that in the animals ordinarily employed for testing 
and evaluating anaesthetics, a renal lesion does not occur with methoxyfluraneoxygen or nitrous oxide-oxygen at a surgical depth of anaesthesia, even after as much as 15 hours ( 3 hours daily $\times 5$ ) or 16 hours ( 4 hours every other day $\times 4$ ). If there is an effect, it is indistinguishable from that produced by surgical anaesthesia with fluroxene, halothane, enflurane and isoflurane. ${ }^{30-36}$

The present report confirms that methoxyflurane is safe when used in the minimum concentration necessary for major operations. To ensure that an excess amount is not used, induction of anaesthesia for major procedures should be carried out with a fast-acting parenteral anaesthetic and a non-depolarizing muscle relaxant. These ensure rapid general anaesthesia, endotracheal intubation and smooth transition to the maintenance agent. Methoxyflurane may then be given with 60 per cent or 50 per cent nitrous oxide and 40 per cent or 50 per cent oxygen from a calibrated temperature- and pressure-compensated vapourizer placed outside the circle system, beginning with 1.0 per cent and reducing the concentration to 0.5 per cent or less when the operation begins. In operations that exceed four hours, the inhaled concentration can usually be reduced gradually until the peritoneum is being closed. Then the vapourizer may be turned off completely during the remainder of the surgical closure without compromising operating conditions. This can be explained by an adequate blood level of methoxyflurane being maintained from at least two sources: some comes out of the body fat and some comes out of the rubber delivery tubes of the gas machine. We reiterate here that only accurately-calibrated temperature- and pressure-compensated vapourizers should be used to accomplish the above. Other vapourizers frequently deliver excess anaesthetic. Adequate pulmonary ventilation (without marked hyperventilation) should be ensured, along with electrolyte and blood replacement both during operation and for as long as is necessary in the post-operative recovery period. Urine output should be measured and recorded as are other vital functions such as blood pressure, pulse rate, heart rhythm and pulmonary ventilation. If urine output falls too low, forced diuresis should be employed at once.

These precautions are mandatory in elderly patients but particularly in those with suspected preexisting renal disease, as well as in very obese patients who usually have multi-system disorders. Only by managing the patients as outlined above can methoxyflurane be considered a safe general anaesthetic.

\section{SUMMARY}

Blood serum inorganic fluoride was measured before, during and after the administration of balanced anaesthesia (91 patients), halothane anaesthesia (101 patients) and methoxyflurane anaesthesia (105 patients) for major abdominal operations. Nitrous oxide and muscle relaxants were used in all patients. Mean age was 45 to 50 years in each group, and mean duration of anaesthesia exceeded 160 minutes.

A slight rise in fluoride ion in the serum from $1.7 \mu \mathrm{M} / \mathrm{L}$ to $2.5 \mu \mathrm{M} / \mathrm{L}$ (mean) occurred in both the balanced anaesthesia and halothane groups. The source that caused the rise in fluorides was not identified even though all possible clues were investigated. It was assumed that the explanation lies in the mobilization of fluo- 
rine from bones or other sources in the body and perhaps trace amounts are in the operating room (from aerosols) and in not easily accessible parts of the anaesthetic machines and respirators.

Methoxyflurane caused about a ten-fold rise in the serum fluoride level in approximately the first hour of administration (from $1.8 \mu \mathrm{M} / \mathrm{L}$ to $15.5 \mu \mathrm{M} / \mathrm{L}$ [mean]), but the highest levels did not exceed that found in drinking water ( $1 \mathrm{ppm}$ or 52 $\mu \mathrm{M} / \mathrm{L}$ ). Thereafter, there did not appear to be an appreciable change with time, indicating perhaps that, at a surgical depth of anaesthesia, fluorine splits off methoxyflurane rapidly in the body, but the kidney is able to excrete it at an adequate rate so that there is no significant accumulation.

We concluded that, in order to avoid undesirable renal effects with methoxyflurane, it should be administered in as low a concentration as is compatible with smooth surgical anaesthesia. Our recommended technique for accomplishing this end is to induce anaesthesia with a non-depolarizing muscle relaxant and a sleep dose of a short-acting barbiturate. After endotracheal intubation, anaesthesia should be maintained with at least 3:2 nitrous oxide:oxygen plus 1 per cent methoxyflurane until the operation begins. Then the concentration of methoxyflurane should be reduced to 0.5 per cent or less. If the surgical procedure is very long ( $>4$ hours), the concentration of methoxyflurane may be further reduced and, in such cases, it may be turned off as soon as surgical closure of the deep layers is underway. Urine output monitoring and concurrent fluid replacement is essential with this anaesthetic.

Other precautions that should be taken include: the use of a vapourizer calibrated for this agent and used for no other, and the avoidance of other vapourizers placed in tandem with it. As always, acute hypoxia, hypercarbia and hypovolaemia should be avoided. Tetracyclines should not be given intravenously during methoxyflurane anaesthesia.

With the above technique, methoxyflurane is not unequivocally contraindicated in any patient except in those with known renal parenchymal disease and perhaps in those who have recently had an anaesthetic with the same agent (within two weeks).

\section{RÉSUM⿻上́}

Le fluore inorganique du sérum fut mesuré avant, pendant et après l'administration de l'anesthésie balancée (91 patients), l'anesthésie à l'halothane (101 patients) et l'anesthésie au méthoxyflurane ( 105 patients) pour la chirurgie majeure abdominale. Le protoxide d'azote et des paralysants musculaires furent utilisés chez tous les patients. L'âge moyen de chacun des groupes variait entre 45 et 50 ans, et la durée moyenne de l'anesthésie dépassait 160 minutes.

Une légère augmentation des ions fluore de $1.7 \mathrm{mM} / \mathrm{L}$ à $2.5 \mathrm{mM} / \mathrm{L}$ (en moyenne) survint chez les groupes d'anesthésie balancée et d'anesthésie à l'halothane. Bien que toutes les possibilités furent étudiées on ne peut mettre en évidence la cause de cette augmentation en fluore. On prétend que cette mobilisation du fluore viendrait des os où d'autres sources dans le corps et peut-être qu'une infime quantité existe dans la salle d'opération (venant des aérosols) et en partie dans les 
machines d'anesthésie et dans les respirateurs, laquelle n'est pas facilement décelable.

Le méthoxyflurane augmente de dix fois le niveau du fluore sérique au cours de la première heure de son administration (de $1.8 \mathrm{mM} / \mathrm{L}$ à $15.5 \mathrm{mM} / \mathrm{L}$ (en moyenne)), mais les plus hauts niveaux ne dépassèrent pas ceuv que l'on trouve couramment dans l'eau que l'on boit ( $1 \mathrm{ppm}$ ou $52 \mathrm{mM} / \mathrm{L}$ ). Par la suite, il n'y eut pas de changement appréciable avec le temps, indiquant peut-être que, à une profondeur chirurgicale de l'anesthésie, le fluore divise rapidement le méthoxyflurane dans le corps, et que le rein peut l'excréter au point qu'il n'y a pas d'accumulation.

Nous avons conclu que, pour éviter les effets rénaux indésirables du méthoxyflurane, nous devions l'utiliser aux plus faibles concentrations compatibles avec une anesthésie chirurgicale. Notre technique recommandée pour arriver à cette fin consiste à débuter l'anesthésie avec un paralysant musculaire non-dépolarisant et une dose hypnotique d'un barbiturique à action courte.

Après l'intubation endotrachéale, l'anesthésie doit être maintenue avec au moins 3:2 protoxyde d'azote : oxygène, plus 1 pour cent de méthoxyflurane jusqu'au début de la chirurgie, puis diminuer la concentration de méthoxyflurane à 0.5 pour cent ou moins. Si le temps chirurgical est très long ( 4 heures), la concentration de méthoxyflurane peut être réduite davantage, et dans ces cas il peut être fermé dès le commencement de la suture des plans profonds. Le dosage du débit urinaire et le remplacement adéquat des liquides est essentiel, avec cet anesthésique. Les autres précautions à prendre sont : se servir d'un vaporisateur calibré pour cet agent et qui ne sert pas à vaporiser d'autres agents, et d'eviter d'autres vaporisateurs placés en série avec celui-ci. Comme toujours il faudra éviter, l'hypoxie aigue, l'hypercarbie et l'hypervolémie. Les tétracyclines ne devront pas être donnés au cours de l'anesthésie au méthoxyflurane.

Avec cette technique le méthoxyflurane n'est pas contre indiqué chez les patients, excepté, chez ceux qui ont une maladie rénale parenchymateuse, connue et peut être aussi chez ceux qui ont eu une anesthésie récente avec le même agent (en dedans de 2 semaines).

\section{ACKNOWLEDGMENT}

The authors are grateful to Dr. Benjamin F. Africa, Miss Judith Dudik, R.N., Mrs. Barbara Esposito, R.N. and John White, B.Sc., for technical assistance and with postoperative followup of the patients in this study.

This work was supported by grants-in-aid from Ayerst Laboratories, Air Reduction Co. Inc., and Abbott Laboratories.

\section{REFERENCES}

1. Prungle, H., Maunsell, R.C.B., \& Pringle, S. Clinical effects of ether anaesthesia on renal activity. Brit. Med. J. 2: 542 (1905).

2. Thompson, W.H. Preliminary note on renal activity during anaesthesia. Brit. Med. J. 1: 649 (1905). 
3. Smith, H.W., Rovenstine, E.A. et al. The effect of spinal anesthesia on the circulation in normal unoperated man with reference to the anatomy of the arteriole and especially to those of the renal circulation. J. Clin. Invest. 18: 319 (1939).

4. Miles, B.E. \& DeWArdener, H.E. Renal vasoconstriction produced by ether and cyclopropane anaesthesia. J. Physiol 118: 140 ( 1952 ).

5. PApper, S. \& Papper, E.M. The effects of preanesthetic, anesthetic and postanesthetic drugs on renal function. Clin. Pharmacol. \& Therap. 5: 205 (1964).

6. Mueller, C.B. The mechanism of acute renal failure after injury and transfusion reaction and its prevention by solute diuresis. Surg. Clin. N.A. 45: 499 (1965).

7. Schreiner, G.E. \& Maher, J.F. Drugs and the kidney. Ann. N.Y. Acad. Sci. 123: 326 (1965).

8. Artusio, J.F., VanPoznak, A., \& Hunt, R.E., et al. A clinical evaluation of methoxyflurane in man. Anesthesiology 21:512 (1960).

9. Paddock, R.B., Parker, J.W., \& Guadagni, N.P. The effects of methoxyflurane on renal function. Anesthesiology 25: 707 (1964).

10. Crandell, W.B., Pappas, S.G., \& MacDonald, A. Nephrotoxicity associated with methoxyflurane anesthesia. Anesthesiology 27: 591 (1966).

11. Doвkin, A.B. Methoxyflurane for major abdominal surgery. Abbott monograph No. 13, Jan. (1968).

12. Dobkin, A.B. \& Byles, P.H. New Inhalation Anesthetics, chapter 12 in A Decade of Clinical Progress, ed. L.W. Fabian. Clinical Anesthesia 3: 295 ( 1969 ).

13. Crandell, W.B. \& MacDonald, A. Nephropathy associated with methoxyflurane anesthesia: a follow-up report. J.A.M.A. 205: 798 (1968).

14. Kuzucu, E.Y. Methoxyflurane, tetracycline and renal failure. J.A.M.A. 211: 1162 (1970).

15. Albers, D.D., LeveretT, C.L. \& Sandin, J.H. Renal failure following prostatovesiculectomy related to methoxyflurane and tetracycline - complicated by Candida infection. J. Urol. 106: 348 (1971).

16. Lapointe, A. \& Bele-Binda, N. Nephrotoxicity associated with methoxyflurane. Canad. Anaesth. Soc. J. 17: 145 (1970).

17. Committee on Anesthesia - National Academy of Sciences - National Research Council: statement regarding the role of methoxyflurane in the production of renal dysfunction. Anesthesiology 34: 505 (1971).

18. Jones, N.O. Methoxyflurane nephrotoxicity - a review and a case report. Canad. Anaesth. Soc. J. 19: 152 ( 1972).

19. Van Dyke, R.A. \& Chenoweth, M.B. Metabolism of volatile anesthetics. Anesthesiology $26: 348(1965)$.

20. Taves, D.R., Fry, B.W., Freeman, R.B., \& Gillies, A.J. Toxicity following methoxyflurane anesthesia. II. Fluoride concentrations in nephrotoxicity. J.A.M.A. 214: 91 (1970).

21. Mazze, R.I., Trudeld, J.R., \& Cousins, M.J. Methoxyflurane metabolism and renal dysfunction: clinical correlation in man. Anesthesiology 35: 247 (1971).

22. Editorial: Fluorides and human health. Lancet $i i$ : 351 (1970).

23. Taves, D.R. New approach to the treatment of bone disease with fluoride. Fed. Proc. 29: $1185(1970)$.

24. Black, M.M., Kleiner, I.S., \& Bolker, H. Toxicity of sodium fluoride in man. N.Y. State J. Med. 49: 1187 (1949).

25. Goldemberg, L. Tratamiento de la enfermedad de Basedow ý del hipertiroidismo por fluor. Rev. Soc. Med. Int. Soc. Tisiolog. 6: 217 (1931).

26. Cousins, M.J., Nishimura, T.G., \& Mazze, R.I. Renal effects of low-dose methoxyflurane with cardiopulmonary bypass. Anesthesiology 36: 278 (1972).

27. Fry, B.W. \& Taves, D.R. Serum fluoride analysis with the fluoride electrode. J. Lab. \& Clin. Med. 75: 1020 ( 1970).

28. Dobkin, A.B., Byles, P.H., \& Arandia, H.Y., et al. Comparative metabolic responses to halogenated anaesthetics. Acta Anaesth. Scandinav. 16: 69 (1972).

29. VAN DYKe, R.A. Personal communication (1972).

30. Doвkin, A.B. \& Fedoruk, S. Comparison of the cardiovascular, respiratory and metabolic effects of methoxyflurane and halothane in dogs. Anesthesiology 22: 355 (1961).

31. Dobkin, A.B. \& Byles, P.H. Comparison of anaesthesia with Innovar, halothane and methoxyflurane-nitrous oxide. Acta Anaesth. Scandinav. 10: Suppl. 18 (1966).

32. Dobkin, A.B., Byles, P.H., \& Neville, J.F., Jr. Neuroendocrine and metabolic effects of general anaesthesia during spontaneous breathing, controlled breathing, mild hypoxia and mild hypercarbia. Canad. Anaesth. Soc. J. 13: 130 (1966). 
33. Dobkin, A.B., Byles, P.H., \& Nevirle, J.F., Jr. Neuroendocrine and metabolic effects of general anaesthesia and graded haemorrhage. Canad. Anaesth. Soc. J. 13: 453 ( 1966 ).

34. Dobkin, A.B., Byles, P.H., Africa, B.F., \& Neville, J.F., Jr. Neuroendocrine and metabolic effects of general anaesthesia associated with acute hypoxia and acute hypercarbia. Canad. Anaesth. Soc. J. 14: 422 (1967).

35. Byles, P.H., Dobkin, A.B., Ferguson, J.H., \& Levy, A.A. Forane (Compound 469). Crossover comparison with enflurane (Ethrane), halothane and methoxyflurane in dogs. Canad. Anaesth. Soc. J. 18: 376 (1971).

36. Byles, P.H., Dobkin, A.B., \& Jones, D.B. Forane (Compound 469). 3. Comparative effects of prolonged anaesthesia on mature beagle dogs and young rhesus monkeys. Canad. Anaesth. Soc. J. 18: 397 (1971). 